\section{Валяровский Федор Иванович}

кандидат юридических наук, доцент, профессор кафедры международного и европейского права Юридического института Пятигорского государственного университета

\section{Цапко Максим Иванович}

кандидат юридических наук, кандидат политических наук, доцент кафедры международного и европейского права Юридического института Пятигорского государственного университета

\section{К ВОПРОСУ О МЕЖДУНАРОДНО-ПРАВОВЫХ ОСНОВАНИЯХ ПРОВОЗГЛАШЕНИЯ НЕЗАВИСИМОСТИ РЕСПУБЛИКИ КРЫМ}

\begin{abstract}
Аннотация:
Статья посвящена рассмотрению международноправовых оснований провозглашения независимости Республики Крым, интерпретации указанных оснований в науке международного права. Проведена сравнительно-правовая характеристика провозглашения независимости Республики Крым и существующих прецедентов провозглашения и признания независимости территорий. Анализируется современное доктринальное толкование соотношения принципов территориальной целостности государств и самоопределения наций в международном праве.
\end{abstract}

Ключевые слова:

международное право, принципы международного права, Республика Крым, независимость, право наций на самоопределение, территориальная целостность государств.
Valyarovskiy Fyodor Ivanovich

PhD in Law, Professor, International and European Law Subdepartment, Law Institute,

Pyatigorsk State University

Tsapko Maxim Ivanovich

PhD in Law, PhD in Political Sciences, Assistant Professor, International and European Law Subdepartment, Law Institute,

Pyatigorsk State University

\section{CONCERNING THE INTERNATIONAL LEGAL GROUNDS FOR THE DECLARATION OF INDEPENDENCE OF THE REPUBLIC OF CRIMEA}

Summary

The article is devoted to consideration of the international legal grounds for the declaration of independence of the Republic of Crimea, the interpretation of these grounds in the science of international law. The article presents a comparative legal analysis of the declaration of independence of the Republic of Crimea and the existing precedents of the proclamation and recognition of the territories independence. The author analyzes the current doctrinal interpretation of the correlation concerning the principle of territorial integrity of states and the principle of national self-determination in international law.

Keywords: international law, principles of international law, $R e$ public of Crimea, independence, right of nations to selfdetermination, territorial integrity of states.

Проблематика соотношения принципа равноправия и самоопределения наций и народов и принципа территориальной целостности государств была и продолжает оставаться одной из важнейших в международных отношениях. Для России этот вопрос существенным образом актуализировался после реализации права на самоопределение населения Республики Крым в ходе референдума 16 марта 2014 г. и последующего вхождения Республики Крым в состав Российской Федерации.

Историко-правовые и государственно-правовые основания провозглашения независимости Республики Крым и дальнейшего воссоединения Крыма с Россией подробно разобраны в работе профрессора В.А. Томсинова [1]. Среди прецедентных ситуаций в указанной работе анализируются, например, прецеденты Аландских островов и Косово. Однако Аландские острова после референдума получили статус автономии, а в Косово полноценный референдум непосредственно перед провозглашением проведен не был. Тем не менее представляется, что именно референдум позволяет наиболее полно и адекватно учесть мнение населения по вопросу самоопределения той или иной территории. Более того, именно референдум в наибольшей степени способствует реализации коллективных прав тех или иных общностей. Существуют прецеденты провозглашения независимости по итогам референдума, которые, думается, заслуживают внимания именно в контексте заявленной проблемы.

Отметим, что имеют место и противоположные точки зрения о возможности провозглашения независимости Республикой Крым. Так, существует мнение, согласно которому провозглашение независимости Крыма не могло иметь международно-правовых оснований, так как принцип территориальной целостности государств имеет преимущество перед принципом, закрепляющим право 
наций на самоопределение. В подкрепление подобной позиции приводятся даже аргументы о том, что территория государства является более значимым и неизменным признаком государства, нежели население, что, на наш взгляд, вступает в противоречие с принципом приоритета прав человека и основных свобод [2]. Также укажем на то, что «Декларация о принципах международного права, касающихся дружественных отношений и сотрудничества между государствами в соответствии с Уставом Организации Объединенных Наций» устанавливает следующее соотношение принципов территориальной целостности государств и права наций на самоопределение [3]. Так, право на самоопределение не может осуществляться жителями государств, «соблюдающих в своих действиях принцип равноправия и самоопределения народов». Соответственно, условием для возможной реализации права на самоопределение является нарушение принципа равноправия и самоопределения народов. Учитывая ситуацию с изменением конституционно-правового статуса Автономной Республики Крым (АРК), фрактически - последовательную ликвидацию прав Крымской автономии в период 1992-1995 гг. (подробное рассмотрение процесса ликвидации конституционного статуса АРК и нарушения ее автономных прав не входит в предмет настоящей статьи), Украину к таковым государствам причислить очень сложно.

Итак, обратимся к примерам провозглашения независимости по итогам референдума, а также примерам готовности и решимости государств признавать итоги референдума по вопросу независимости, обозначенным в юридических документах.

Путем проведения референдума и дальнейшего провозглашения независимости на основе его результатов право на самоопределение было реализовано в Эритрее, Восточном Тиморе (Тимор-Лешти) и Южном Судане [4]. Эти государства являются сегодня членами Организации Объединенных Наций.

Что касается примеров готовности и решимости государств признавать итоги референдума по вопросу независимости, обозначенным в юридических документах, можно указать на следующее. 15 ноября 1985 г. было принято англо-ирландское соглашение в Хиллсборо, в статье первой которого говорится: «...Если в будущем большинство народа Северной Ирландии выразит ясное желание и формальное согласие основать Объединенную Ирландию, они представят и поддержат в соответствующих парламентах законодательство, чтобы придать силу этому стремлению» [5].

Субъектом права на самоопределение является народ (нация), и, несмотря на то что у этого термина множество трактовок (в разных языках слово «нация», например, имеет разное значение), мнение о том, что субъектом этого права может быть этническая или религиозная группа, достаточно широко распространено. В Автономной Республике Крым проживало несколько этнических групп: русские, украинцы и крымские татары. Украина за достаточно длительный период независимости не смогла решить вопрос о статусе языков крупнейших этнических групп АРК. Говорить о соблюдении коллективных прав в данной ситуации не приходится вовсе.

Автономия в Крыму фактически ликвидирована Украиной в одностороннем порядке в период осени 1994 - весны 1995 г. Отметим, что провозглашение народом Крыма автономии в 1991 г. (посредством референдума) как минимум косвенно указывает на состоявшуюся политико-правовую субъектность народа Крыма. Именно провозглашением автономии уже было реализовано право народа Крыма на самоопределение в составе УССР. Путем фактически насильственного лишения народа Крыма этого права (на автономию) и состоялось грубое нарушение его коллективных прав.

Таким образом, даже без учета историко-правовых и конституционно-правовых аспектов статуса Крыма можно констатировать достаточность оснований и завершенность процедуры реализации права на самоопределение народа Крыма с точки зрения международного права. Как и любое подобное событие в международных отношениях, провозглашение независимости Республики Крым по-своему уникально, и, разумеется, оно реализовано не идеально с формальноюридической и юридико-технической точек зрения. С позиции конституционного права в дальнейшем необходимо провести референдумы о Конституции Республики Крым и об Уставе города федерального значения Севастополь.

Полагаем, что приоритет исторического или этнического в решении вопроса о самоопределении должен определяться индивидуально для каждого случая исходя из конкретно-исторических условий. Однако признание приоритета этнического перед историческим всякий раз должно происходить с оглядкой на порой весьма высокие темпы миграции в современном мире и потенциальную возможность использования миграции для определения статуса тех или иных территорий. Фактически так произошло в случае с Косово. Полагаем, историческое право должно все-таки иметь приоритет перед этническим.

В заключение перечислим условия, достаточные для реализации права на самоопределение: нарушение государством, на территории которого пребывает самоопределяющаяся общность, принципа равноправия и самоопределения народов; наличие историко-правовых оснований самоопределения; проведение референдума, волеизъявление в рамках которого должно 
осуществляться не в отдельных этнических или этноконфессиональных общинах, но среди всего населения самоопределяющейся территории.

\section{Ссылки:}

1. Томсинов В.А. «Крымское право», или Юридические основания для воссоединения Крыма с Россией // Вестник Московского университета. Серия 11 «Право». 2014. С. 3-32.

2. Саяпин С.В. Современные вызовы международному праву [Электронный ресурc]. URL: http://www.zakon.kz/4681800sovremennye-vyzovy-mezhdunarodnomu.html\# (дата обращения: 06.02.2017).

3. Декларация о принципах международного права, касающихся дружественных отношений и сотрудничества между государствами в соответствии с Уставом Организации Объединенных Наций [Электронный ресурс] : принята резолюцией 2625 (XXV) Генеральной Ассамблеи ОOH от 24 окт. 1970 г. URL: http://www.un.org/ru/documents/decl_conv/declarations/intlaw_principles.shtml (дата обращения: 06.02.2017).

4. Bassil N.R. The Crisis of the Post-Colonial Sudanese State: Origins of the Conflict in Darfur. London, 2015.

5. Буханова А.С. Коллизия принципов самоопределения народов, территориальной целостности государств и возможные пути ее решения // Право и управление: XXI век. 2011. № 4 (21). С. 67-71.

\section{References:}

Bassil, NR 2015, The Crisis of the Post-Colonial Sudanese State: Origins of the Conflict in Darfur, London.

Bukhanova, AS 2011, 'Collision of the principles of self-determination of peoples, territorial integrity of states and possible ways of its solution', Pravo i upravleniye: XXI vek, no. 4 (21), pp. 67-71, (in Russian)

Sayapin, SV 2017, Modern challenges to international law, viewed 06 February 2017, <http://www.zakon.kz/4681800-sovremennye-vyzovy-mezhdunarodnomu.html\#>, (in Russian).

Tomsinov, VA 2014, '“Crimean law", or Legal grounds for the reunification of the Crimea with Russia', Vestnik Moskovskogo universiteta. Seriya 11 "Pravo", pp. 3-32, (in Russian). 